Revista Eletrônica de Direito Processual - REDP.

Rio de Janeiro. Ano 11. Volume 18. Número 1. Janeiro a Abril de 2017

Periódico Quadrimestral da Pós-Graduação Stricto Sensu em Direito Processual da UERJ

Patrono: José Carlos Barbosa Moreira. ISSN 1982-7636. pp. 325-345

www.redp.uerj.br

\title{
O IMPACTO DAS CONVENÇÕES PROCESSUAIS SOBRE A LIMITAÇÃO DE MEIOS DE PROVA ${ }^{1}$
}

\section{THE IMPACT OF PROCEDURAL CONVENTIONS ON THE LIMITATION OF MEANS OF EVIDENCE}

\section{Marco Félix Jobim}

Mestre e Doutor em Direito. Pós-doutorando em Direito pela Universidade Federal do Paraná. Advogado e Professor dos Programas de Graduação e pós-graduação lato e stricto sensu da Pontifícia Universidade Federal do Rio Grande do Sul. marco@jobimesalzano.com.br

Bruna Bessa De Medeiros

Advogada. Pós-graduanda em Direito Processual Civil pela PUC/RS.

RESUMO: O estudo objetiva analisar a possibilidade de vinculação das partes e do juiz a uma convenção processual limitadora dos meios de prova, tendo em vista a finalidade do processo de buscar uma decisão justa.

PALAVRAS-CHAVE: novo Código de Processo Civil - autorregramento da vontade convenções processuais - direito probatório - poder instrutório - decisão justa - verdade.

ABSTRACT: This article seeks to analyze the possibility of legally binding the parties and the judge to a limiting procedural agreement of evidence, in order to conclude the procedures in a just decision.

KEYWORDS: new Civil Procedure Code - autonomy of the will - procedural agreement - law of evidence - judicial powers - just decision - truth.

\footnotetext{
${ }^{1}$ Artigo recebido em 07/03/2017 aprovado em 18/04/2017.
} 
Revista Eletrônica de Direito Processual - REDP.

Rio de Janeiro. Ano 11. Volume 18. Número 1. Janeiro a Abril de 2017

Periódico Quadrimestral da Pós-Graduação Stricto Sensu em Direito Processual da UERJ

Patrono: José Carlos Barbosa Moreira. ISSN 1982-7636. pp. 325-345

www.redp.uerj.br

SUMÁRIO: Introdução. 1. Considerações inicias sobre o modelo de processo clamado pela Lei n. 13.105/2015. 2. Prova, verdade e processo - 3. Convenções processuais sobre limitação a meios de prova - 4. Considerações Finais - Referencial Bibliográfico.

\section{INTRODUÇÃO:}

O novo modelo de Processo Civil brasileiro tem história recente, com o Ato n. 379, do então Presidente do Senado Federal José Sarney, em 2009, instituindo uma comissão de juristas que se encarregaria da elaboração de um Anteprojeto de Lei que tratasse da nova legislação processual civil brasileira, sendo a comissão Presidida pelo então Ministro do Superior Tribunal de Justiça Luiz Fux, hoje à frente do Supremo Tribunal Federal, acompanhado de equipe de processualistas de renome nacional. Em 2010 o Anteprojeto foi apresentado no Congresso Nacional e convertido no Projeto de Lei do Senado n. 166/2010, tendo seu relatório final sido aprovado em $1^{\circ}$ de dezembro, sendo, então, remetido para a Câmara de Deputados, no qual foi recebido como Projeto de Lei n. 8.046/10.

Maiores detalhes da tramitação desimportam neste momento, sendo que, em março de 2015, com a sanção presidencial, o novo modelo de processo civil brasileiro, com vigência para 18 de março do ano subsequente, tomou forma final e está em pleno andamento com um ano já de sua vigêcia, tomando como base a data de fechamento do presente artigo tendo, inclusive, já sido a lei processual reformada em alguns pontos interessantas, mas que fogem do alcance do presente estudo.

Mas o modelo processual é novo? A resposta passa, necessariamente, pelo estudo dos dispositivos legais que teriam a força para confirmar a pergunta, sendo inegável que não poderia faltar à argumentação da resposta o que pode ser considerado uma imensa novidade, pelo menos a forma atípica, que é a possibilidade de negócio, acordo ou conveção processual talhada no art. 190 da legislação, sendo este o norte perseguido no artigo, direcionando-o para o direito probatório. Antes, evidentemente, há algumas considerações a serem realizadas sobre o modelo processual que o CPC/2015 aponta. 
Revista Eletrônica de Direito Processual - REDP.

Rio de Janeiro. Ano 11. Volume 18. Número 1. Janeiro a Abril de 2017

Periódico Quadrimestral da Pós-Graduação Stricto Sensu em Direito Processual da UERJ

Patrono: José Carlos Barbosa Moreira. ISSN 1982-7636. pp. 325-345

www.redp.uerj.br

1. Considerações inicias sobre o modelo de processo clamado pela Lei n.

13.105/2015.

Um dos grandes nortes idealizados pelo legislador no Código de Processo Civil de 2015 foi inserir no texto o direito fundamental à liberdade, em sua dimensão processual que, nas palavras de Júlia Lipiani e Marília Siqueira ${ }^{2}$ estão sustentadas nos dispositivos relacionados aos negócios ou convenções processuais e ao estímulo dos meios adequados ou alternativos de resolução de controvérsias ${ }^{3}$. Essa leitura realizada da liberdade como fundamento do art. 190, CPC/2015, é possível por alguns fatores já conhecidos, como a Constituição Federal figurar no topo do ordenamento jurídico e, em especial, para o enfrentamento dos tópicos do presente estudo, pela redação do art. $1^{\circ}$ do CPC/2015 que trata sobre a constitucionalização do processo. Assim, é possível afirmar que o processo civil brasileiro se encontra em uma quarta fase metodológica ou cultural do processo que pode ser chamada de nomes como formalismo-valorativo ${ }^{4}$, neoprocessualismo ${ }^{5}$ ou de um processo civil no Estado Constitucional ${ }^{6}$, dentre outras que poderiam ser lembradas.

Essa nova, ou não tão nova fase metodológica do processo, qualquer que seja a sua denominação, tem a intenção de superar a fase da instrumentalidade do processo ${ }^{7}$. Dentre as

${ }^{2}$ LIPIANI, Júlia; SIQUEIRA, Marília. Negócios jurídicos processuais sobre mediação e conciliação. ZANETI JR., Hermes; CABRAL, Trícia Navarro Xavier (coordenadores); DIDIER JR., Fredie (coordenador geral). Justiça multiportas: mediação, conciliação, arbitragem e outros meios de solução adequada de conflitos. Salvador: Juspodivm, 2017. p. 141. Referem: "Liberdade. Ao que nos parece, esta é a palavra de ordem do novo Código de Processo Civil (CPC), tendo dois eixos principais de sustentação: celebração de negócios processuais típicos e atípicos pelas partes e estímulo à utilização dos métodos alternativos de solução de controvérsias. O próprio órgão julgador passa a ter, também, um espaço de liberdade mais amplo para a adequação das regras processuais ao caso concreto".

${ }^{3}$ Para saber mais sobre o impacto, recomenda-se a leitura: ZANETI JR., Hermes; CABRAL, Trícia Navarro Xavier (coordenadores); DIDIER JR., Fredie (coordenador geral). Justiça multiportas: mediação, conciliação, arbitragem e outros meios de solução adequada de conflitos. Salvador: Juspodivm, 2017.

${ }^{4}$ Fase criada pela Escola da Universidade Federal do Rio Grande do Sul, que determina dois parâmetros para nortear a interpretação do processo civil: efetividade e segurança jurídica. (JOBIM, Marco Felix. Cultura, escolas e fases metodológicas do processo. $3^{\mathrm{a}}$ ed. rev. atual. De acordo com o novo CPC. Porto Alegre: Livraria do Advogado Editora, 2016. p. 156 e 160)

${ }^{5}$ Fase pensada por Fredie Didier Jr., sem princípios norteadores, em busca de um processo efetivo. (Ibid., p. 158)

${ }^{6}$ Em crítica às denominações anteriores, Daniel Mitidiero intitula esta quarta fase metodológica de processo civil no Estado Constitucional. (MITIDIERO, Daniel. Colaboração no Processo Civil: pressupostos sociais, lógicos e éticos. $3^{\text {a }}$ ed. rev. atual. e ampl. de acordo com o novo código de processo civil. São Paulo: Editora Revista dos Tribunais, 2015. p. 48/49)

${ }^{7}$ Em que pese, obviamente, haver discordância sobre a afirmação: BEDAQUE, José Roberto dos Santos. Direito e processo: influência do direito material sobre o processo. 5. ed. São Paulo: Malheiros, 2009. p. 17. Afirma o processualista: "A ciência processual no Brasil encontra-se na fase de sua evolução que autorizada 
Revista Eletrônica de Direito Processual - REDP.

Rio de Janeiro. Ano 11. Volume 18. Número 1. Janeiro a Abril de 2017

Periódico Quadrimestral da Pós-Graduação Stricto Sensu em Direito Processual da UERJ

Patrono: José Carlos Barbosa Moreira. ISSN 1982-7636. pp. 325-345

www.redp.uerj.br

suas concepções, determina que o processo deve ser lido à luz da Constituição Federal e compreendido em um Estado Democrático de Direito ou Estado Constitucional, com respeito aos direitos fundamentais e valores constitucionais. Para que se atenda aos pressupostos culturais do Estado Constitucional, a doutrina aponta para um novo modelo de processo, em superação aos modelos adversarial e inquisitorial ${ }^{8}$, ou aos modelos isonômico e assimétrico $\%^{9}$, embora exista resquícios dos mesmos durante a fase de tramitação processual. Este novo modelo de processo, denominado modelo cooperativo, é caracterizado por buscar uma divisão equilibrada de trabalho entre juiz e partes, no qual todos trabalham em conjunto ${ }^{11}$ ou comparticipativa ${ }^{12}$, sem o protagonismo de apenas um dos atores ${ }^{13}$. Essa divisão de trabalho propicia um processo mais justo, democrático, tendo em vista a participação ativa dos sujeitos e encontra-se estampado na redação do art. $6^{\circ}$ do CPC/2015. O princípio basilar deste modelo - da colaboração - garante o direito à participação e à igualdade $^{14}$, bem como é a concretização de valorização da vontade no processo ${ }^{15}$. Deste modo, o contraditório ganha maior relevância, tendo em vista que deve ser efetivo e não meramente formal ou ilusório, de modo que possibilite a influência das partes no convencimento do juiz ${ }^{16}$, garantindo-lhe a não surpresa das decisões judiciais, conforme

doutrina identifica como instrumentalista. É a conscientização de que a importância do processo está em seus resultados".

${ }^{8}$ DIDIER JR. Fredie. Curso de Direito Processual Civil, V. I. $18^{\mathrm{a}}$ Ed. Salvador: Editora Jus Podivm, 2016. pg. 127

${ }^{9}$ MITIDIERO, Op. cit. pg. 53

${ }^{10}$ Para o presente estudo, seguiremos o entendimento de Daniel Mitidiero, que analisa o novo modelo de processo para além das posições jurídicas das partes e do juiz, fazendo um estudo aprofundado dos pressupostos sociais, lógicos e éticos que favoreceram a comparação e consequente superação dos modelos de processo referidos anteriormente, em prol do novo modelo cooperativo. $\mathrm{O}$ modelo cooperativo tem como pressuposto social a promoção dos deveres constitucionais, "objetivando 'construir uma sociedade livre, justa e solidária' (artigo 3, I, CF/1988)" - (pg. 64); como pressuposto lógico identifica o caráter problemático do direito e adota uma lógica dialética, com observância ao contraditório efetivo (pg. 85/90); como pressuposto ético a busca da verdade provável e a observância à boa-fé subjetiva e objetiva (pg. 90/97) Ademais, o autor reconhece que estão preservados no novo modelo de processo traços dos modelos adversarial e inquisitorial, motivo pelo qual o terceiro modelo não pode ser considerado uma superação dos destes. (Ibid., p. 53-54).

${ }^{11}$ Ibid., p. 46.

${ }^{12}$ Para melhor compreensão do processo comparticipativo, recomenda-se a leitura: THEODORO JÚNIOR, Humberto; NUNES, Dierla; BAHIA, Alexandre Melo Franco; PEDRON, Flávio Quinaud. Novo CPC: fundamentos e sistematização. Rio de Janeiro: Forense, 2015.

13 ABREU, Rafael Sirangelo de. "Customização processual compartilhada": o sistema de adaptabilidade do novo CPC. Revista de Processo, vol. 257, jul/2016 - pg. 52

${ }^{14}$ ABREU, Op. cit., p. 56.

${ }^{15}$ DIDIER JR., Fredie. Princípio do respeito ao autorregramento da vontade no processo civil. In: CABRAL, Antonio do Passo; NOGUEIRA, Pedro Henrique (coord.). Negócios Processuais. $2^{\mathrm{a}}$ ed., rev., atual., ampl. Salvador, Ed. Juspodivm, 2016 - pg. 37

${ }^{16}$ MITIDIERO, Op. cit., p. 89 
Revista Eletrônica de Direito Processual - REDP.

Rio de Janeiro. Ano 11. Volume 18. Número 1. Janeiro a Abril de 2017

Periódico Quadrimestral da Pós-Graduação Stricto Sensu em Direito Processual da UERJ

Patrono: José Carlos Barbosa Moreira. ISSN 1982-7636. pp. 325-345

www.redp.uerj.br

artigos $9^{\circ}$ e $10^{\circ}, \mathrm{CPC} / 2015$. Assim, durante a condução do processo, o juiz deve ser paritário, enquanto na hora de decidir, deve ser assimétrico ${ }^{17}$. Sendo assim, pode-se considerar que, em comparação com o Código de processo Civil de 1973, o novo Código de Processo Civil possibilita maior atuação das partes no processo, com maior espaço ao autorregramento da vontade $^{18}$, que passaram a atuar de forma equilibrada com a atuação do juiz.

Como consequência desta divisão de trabalho entre juiz e partes, há um "esvaziamento do poder do juiz no novo CPC"19, em relação ao Código anterior, que pode ser verificado por dispositivos ao longo do código que acabaram por "outorgar espaços de autodeterminação das partes" ${ }^{20}$, como, por exemplo, o saneamento consensual do processo ${ }^{21}$ e a indicação consensual do perito ${ }^{22}$. Por outro lado, verifica-se ainda espaços de atuação estatal, tais como poder de direção e situações de possível iniciativa subsidiária ${ }^{23}$.

Mesmo o Código de Processo Civil de 1973, caracterizado por hipervalorizar a forma e por ser assimétrico na condução do processo, já previa hipóteses de convenções processuais típicas, tais como: cláusula de eleição de foro (art. 111, CPC/73), suspensão convencional do processo (art. 265, II, CPC/73), adiamento da audiência de instrução e julgamento (art. 453, I, CPC/73), entre outras, sendo que, até mesmo leis extravagantes, como a Lei n. 8.245/91, continha previsão de negócio processual, em seu Art. 58, IV, ao referir que havendo autorização no contrato, a citação, intimação ou notificação far - se - á mediante correspondência com aviso de recebimento, ou, tratando - se de pessoa jurídica

\footnotetext{
${ }^{17}$ Ibid., p. 72.

${ }^{18}$ ABREU, Op. cit., p. 60.

19 JOBIM, Op. cit., p. 181.

${ }^{20}$ Elenca-se, exemplificativamente, a liberdade de iniciativa (art. $2^{\circ}$ ), as abdicações em geral a respeito de posições processuais (art. 998, parágrafo único), a relevância da vontade em certos atos omissivos (art. 65, art. 337 parágrafo $6^{\circ}$, e art. 1.000) - (ABREU, Op. cit., p. 55/56).

${ }^{21}$ Art. 357, CPC/15: Não ocorrendo nenhuma das hipóteses deste Capítulo, deverá o juiz, em decisão de saneamento e de organização do processo: I - resolver as questões processuais pendentes, se houver;II delimitar as questões de fato sobre as quais recairá a atividade probatória, especificando os meios de prova admitidos; III - definir a distribuição do ônus da prova, observado o art. 373; IV - delimitar as questões de direito relevantes para a decisão do mérito; $V$ - designar, se necessário, audiência de instrução e julgamento. $\S 1^{\circ}$ Realizado o saneamento, as partes têm o direito de pedir esclarecimentos ou solicitar ajustes, no prazo comum de 5 (cinco) dias, findo o qual a decisão se torna estável. \$ $2^{\circ}$ As partes podem apresentar ao juiz, para homologação, delimitação consensual das questões de fato e de direito a que se referem os incisos II e IV, a qual, se homologada, vincula as partes e o juiz.

${ }^{22}$ Art. 373, $\S 3^{\circ}, C P C / 15:$ A distribuição diversa do ônus da prova também pode ocorrer por convenção das partes, salvo quando:I - recair sobre direito indisponível da parte; II - tornar excessivamente difícil a uma parte o exercício do direito.

${ }^{23}$ ABREU, Op. cit., p. 56.
} 
Revista Eletrônica de Direito Processual - REDP.

Rio de Janeiro. Ano 11. Volume 18. Número 1. Janeiro a Abril de 2017

Periódico Quadrimestral da Pós-Graduação Stricto Sensu em Direito Processual da UERJ

Patrono: José Carlos Barbosa Moreira. ISSN 1982-7636. pp. 325-345

www.redp.uerj.br

ou firma individual, também mediante telex ou fac-símile, ou, ainda, sendo necessário, pelas demais formas previstas no Código de Processo Civil.

O Código de Processo Civil de 2015 acabou por ampliar as hipóteses de convenções processuais típicas ${ }^{24}$. Porém, uma das grandes inovações do Novo Código foi a implementação de uma cláusula geral de convenção processual, no seu artigo $190^{25} / 26$, que permite a conformação do procedimento e posições processuais por meio da autonomia da vontade. Esta cláusula aberta permite, portanto, a customização processual para tornar o processo mais adequado às necessidades e vontades das partes ${ }^{27}$, em atenção a uma das principais finalidades do Estado Constitucional, qual seja, a liberdade ${ }^{28}$.

A cláusula geral permite que, em se tratando de direito que admita autocomposição, as partes capazes possam estipular mudanças no procedimento e convencionar sobre seus ônus, poderes, faculdades e deveres processuais. Portanto, pode ser considerada um desdobramento do modelo cooperativo, posto que acaba por concretizar essa possibilidade de maior atuação das partes na condução do processo, bem como "fortalece a ideia de processo justo, pois é um dos modos de realizar o contraditório efetivo, porquanto confere, de forma legítima, mecanismo para que as partes possam intervir na solução do litígio". ${ }^{29}$

\footnotetext{
${ }^{24}$ Por exemplo, incluiu no rol das convenções típicas o saneamento consensual (art. $357, \S 2^{\circ}, \mathrm{CPC} / 15$ ), a escolha consensual do perito (art. 471, CPC/15), a calendarização processual (art. 191, CPC/15), entre outras.

${ }^{25} \mathrm{~A}$ inovação em questão diz respeito à positivação da cláusula geral de convenções processuais no ordenamento jurídico brasileiro, que acaba por sanar a divergência sobre a existência ou não desse instituto no direito brasileiro. Neste sentido, ver CUNHA, Leonardo Carneiro da. Negócios Jurídicos Processuais no Processo Civil Brasileiro. In: CABRAL, Antonio do Passo; NOGUEIRA, Pedro Henrique (coord.). Negócios Processuais. 2a ed., rev., atual., ampl. - Salvador, Ed. Juspodivm, 2016 - pg. 46/54; no mesmo sentido, Antonio do Passo. Convenções processuais. Salvador: Editora JusPodivm, 2016 - pg. 114/133

${ }^{26}$ Art. 190, CPC/15: Versando o processo sobre direitos que admitam autocomposição, é lícito às partes plenamente capazes estipular mudanças no procedimento para ajustá-lo às especificidades da causa e convencionar sobre os seus ônus, poderes, faculdades e deveres processuais, antes ou durante o processo. Parágrafo único. De ofício ou a requerimento, o juiz controlará a validade das convenções previstas neste artigo, recusando-lhes aplicação somente nos casos de nulidade ou de inserção abusiva em contrato de adesão ou em que alguma parte se encontre em manifesta situação de vulnerabilidade

${ }^{27}$ ABREU, Op. cit., p. 60

${ }^{28}$ Ibid., p. 63.

${ }^{29}$ SILVA, Beclaute de Oliveira da Silva. Verdade como objeto do negócio jurídico processual. In: CABRAL, Antonio do Passo; NOGUEIRA, Pedro Henrique (coord.). Negócios Processuais. 2a ed., rev., atual., ampl. - Salvador, Ed. Juspodivm, 2016 - pg. 541
} 
Revista Eletrônica de Direito Processual - REDP.

Rio de Janeiro. Ano 11. Volume 18. Número 1. Janeiro a Abril de 2017

Periódico Quadrimestral da Pós-Graduação Stricto Sensu em Direito Processual da UERJ

Patrono: José Carlos Barbosa Moreira. ISSN 1982-7636. pp. 325-345

www.redp.uerj.br

Assim sendo, tendo em vista que a prova pode ser considerada como um direito ${ }^{30}$, um ônus ${ }^{31}$ e até mesmo um dever ${ }^{32}$, por meio desta cláusula geral, haveria a possibilidade de as partes convencionarem sobre a limitação dos meios probatórios. Isto, pois, a prima facie, a autonomia privada seria limitada apenas pela nulidade, inserção abusiva em contrato de adesão ou quando alguma das partes se encontrar em manifesta situação de vulnerabilidade (parágrafo único do artigo 190, CPC/15).

Entretanto, tal assertiva merece um estudo mais aprofundado, tendo em vista a constitucionalização do processo $\operatorname{civil}^{33}$ e a sua busca por uma decisão de mérito justa e efetiva (art. $\left.6^{\circ}, \mathrm{CPC}\right)$.

\section{Prova, verdade, processo e limitações legais à prova}

A verdade é apenas uma, objetiva, que independe de crença ou convencimento; refere-se àquilo que realmente aconteceu ${ }^{34 / 35}$. Portanto, partindo deste pressuposto, a verdade no processo é inalcançável, tendo em vista que a instrução probatória diz respeito a fatos pretéritos. Isto, pois "a reconstrução de um fato ocorrido no passado sempre vem influenciada por aspectos subjetivos das pessoas que o assistiram, ou ainda do juiz, que há de valorar a evidência concreta" ${ }^{36}$.Não bastasse, as afirmações feitas pelas partes serão

${ }^{30}$ A Constituição Federal garante o direito à produção de provas, tendo em vista o princípio do devido processo legal, do contraditório e da ampla defesa (NEVES, Daniel Amorim Assumpção. Manual de Direito Processual Civil. Volume único. 8. Ed. Salvador: Juspodivm, 2016. p. 649-650).

${ }^{31} \mathrm{Na}$ realidade, o ônus da prova é uma regra de instrução, pois tem como objetivo "informar as partes quem suporta o risco de ausência de esclarecimento as alegações de fato no processo", bem como uma regra de julgamento, posto que visa "possibilitar ao juiz decidir quando em estado de dúvida quanto à veracidade das alegações fáticas", isto é, quando não há provas suficientes. (MARINONI, Luiz Guilherme; ARENHART, Sergio Cruz; MITIDIERO, Daniel. Novo curso de processo civil: teoria do processo civil. 2. Ed. São Paulo: Revista dos Tribunais, 2016. p. 509).

${ }^{32}$ RAMOS, Vitor de Paula. Ônus da prova no processo civil: do ônus ao dever de provar. São Paulo: Revista dos Tribunais, 2015. p. 93/116.

${ }^{33}$ Um dos objetivos fundamentais da República Federativa do Brasil é a construção de uma sociedade livre, justa e solidária (art. $3^{\circ}, \mathrm{I}, \mathrm{CF}$ ). Ainda, no preâmbulo, está assegurada a justiça como valor supremo a ser seguido.

${ }^{34}$ RAMOS, Op. cit., p. 26.

${ }^{35}$ Carnelutti já afirmava que “A verdade é como a água: ou é pura ou não é verdade. Quando a procura da verdade material é limitada no sentido de que esta não possa ser em cada caso e com cada meio conhecida, seja limite colocado mais ou menos rigoroso, o resultado é sempre este: que não se trata mais de uma procura da verdade material, mas de um processo de fixação formal dos fatos". (CARNELUTTI, Francesco. A prova civil. Trad. Amilcare Carletti. São Paulo: Livraria e Editora Universitária de Direito, 2002. p. 53).

${ }^{36}$ MARINONI, Luiz Guilherme; ARENHART, Sergio Cruz. Prova e convicção: de acordo com o CPC de 2015. São Paulo: Revista dos Tribunais, 2015. p. 39. 
Revista Eletrônica de Direito Processual - REDP.

Rio de Janeiro. Ano 11. Volume 18. Número 1. Janeiro a Abril de 2017

Periódico Quadrimestral da Pós-Graduação Stricto Sensu em Direito Processual da UERJ

Patrono: José Carlos Barbosa Moreira. ISSN 1982-7636. pp. 325-345

www.redp.uerj.br

tendenciosas, posto que são interessadas na questão. ${ }^{37 / 38}$ Desse modo, o juiz, embora o processo seja pautado pela busca da verdade, jamais a alcançará, pelo menos tendo esta certeza $^{39}$.

Tem-se que o "conhecimento dos fatos é pressuposto para a aplicação do direito"40/41. Todavia, prova não objetiva a reconstrução dos fatos, mas sim o convencimento do juiz sobre as alegações feitas pelas partes ${ }^{42}$.

Além da subjetividade da percepção dos fatos, tanto pelas partes, quanto pelas testemunhas e juiz, ainda há uma limitação à produção de provas imposta pelo próprio Código de Processo Civil. Está expresso no Novo Código - assim como já estava no Código revogado $^{43}$ - que o juiz indeferirá as provas inúteis ou protelatórias (artigo 370, parágrafo único, $\mathrm{CPC} / 15^{44}$ ); além disso, independem de prova os fatos notórios, confessados, incontroversos e presumidos verdadeiros de forma absoluta (artigo 374 do CPC de $2015^{45}$ ). Deste modo, "deverão ser provados apenas os fatos sobre os quais exista controvérsia e que sejam relevantes à solução do litígio"46.

Outrossim, estão presentes no Código dispositivos que permitem a escusa na produção de provas, tais como o artigo $388^{47}$, que exonera a prestação de depoimento pessoal

${ }^{37}$ GODINHO, Robson. A possibilidade de negócios jurídicos processuais atípicos em matéria probatória. In: CABRAL, Antonio do Passo; NOGUEIRA, Pedro Henrique (coord.). Negócios Processuais. 2. Ed. Salvador: Juspodivm, 2016. p. 551

${ }^{38}$ Calamandrei, neste sentido, alega que "a história que escreve o juiz, não é simplesmente a história da verdade, senão que é mais bem a história do jogo através do qual uma das partes tem conseguido fazer triunfar no processo, secundum allegata et probata, sua verdade." (CALAMANDREI, Piero. Direito processual civil. V. 3. Trad. Luiz Abezia e Sandra Drina Fernandez Barbiery. Campinas: Bookseller, 1999. p. 243).

${ }^{39}$ MARINONI; ARENHART, Op. cit., p. 46.

${ }^{40}$ Os autores, Marinoni e Arenhart, ao fazerem esta afirmação, oferecem uma crítica a este entendimento. MARINONI; ARENHART, op. cit., p. 29.

${ }^{41}$ Carnelutti afirmava que o significado de prova era "a demonstração da verdade de um fato dada com os meios legais (por legítimos modos) ou, mais brevemente, demonstração da verdade legal de um fato". (CARNELUTTI, 2002, p. 72).

${ }^{42}$ MARINONI; ARENHART, op. cit., p. 63.

${ }^{43}$ Arts. 130 e 334 do CPC/73.

${ }^{44}$ Art. 370, CPC/15. Caberá ao juiz, de ofício ou a requerimento da parte, determinar as provas necessárias ao julgamento do mérito. Parágrafo único. O juiz indeferirá, em decisão fundamentada, as diligências inúteis ou meramente protelatórias.

${ }^{45}$ Art. 374, CPC/15. Não dependem de prova os fatos: I - notórios; II - afirmados por uma parte e confessados pela parte contrária; III - admitidos no processo como incontroversos; IV - em cujo favor milita presunção legal de existência ou de veracidade.

${ }^{46}$ AMARAL, Paulo Osternack. Provas: atipicidade, liberdade e instrumentalidade. São Paulo: Revista dos Tribunais, 2015. p. 32.

${ }^{47}$ Art. 388, CPC/15: A parte não é obrigada a depor sobre fatos:I - criminosos ou torpes que lhe forem imputados; II - a cujo respeito, por estado ou profissão, deva guardar sigilo; III - acerca dos quais não possa responder sem desonra própria, de seu cônjuge, de seu companheiro ou de parente em grau sucessível; IV que coloquem em perigo a vida do depoente ou das pessoas referidas no inciso III. Parágrafo único. Esta 
Revista Eletrônica de Direito Processual - REDP.

Rio de Janeiro. Ano 11. Volume 18. Número 1. Janeiro a Abril de 2017

Periódico Quadrimestral da Pós-Graduação Stricto Sensu em Direito Processual da UERJ

Patrono: José Carlos Barbosa Moreira. ISSN 1982-7636. pp. 325-345

www.redp.uerj.br

em situações em que a parte tem o direito de silêncio, e o artigo $404^{48}$, que exonera a parte

ou terceiro que tem motivo relevante para a não apresentação de documento ou coisa em juízo.

Não bastasse isso, o Código prevê, ainda, que as partes podem se eximir de produzir provas contra si mesmas. O caput do artigo 379 do CPC/15 determina que seja preservado o direito de a parte não produzir provas contra si própria. ${ }^{49}$ Todavia, tal assertiva é passível de divergências. Há quem entenda que este direito - e consequente limitação do "dever" de provar - diz respeito apenas quando se tratar de proteção contra reflexos no âmbito penal ${ }^{50}$. Em contrapartida, pode ser entendido que este direito está relacionado às garantias do devido processo legal, como o direito à ampla defesa, e, portanto, aplicável também quando as consequências incidirem apenas no âmbito civil ${ }^{51 / 52 / 53}$. Sob esta ótica, a prova não é um dever, mas apenas uma faculdade. Nesta senda, importante salientar que o dever de colaboração, previsto pelo modelo cooperativo de processo, é apenas do juiz para com as partes e não das partes entre si, diante as suas posições antagônicas no processo ${ }^{54}$. Sendo assim, o ato de provar em favor da parte contrária não pode ser considerado um dever.

\footnotetext{
disposição não se aplica às ações de estado e de família.

${ }^{48}$ Art. 404, CPC/15: Art. 404. A parte e o terceiro se escusam de exibir, em juízo, o documento ou a coisa se:I - concernente a negócios da própria vida da família; II - sua apresentação puder violar dever de honra; III - sua publicidade redundar em desonra à parte ou ao terceiro, bem como a seus parentes consanguíneos ou afins até o terceiro grau, ou lhes representar perigo de ação penal; IV - sua exibição acarretar a divulgação de fatos a cujo respeito, por estado ou profissão, devam guardar segredo; $V$ - subsistirem outros motivos graves que, segundo o prudente arbítrio do juiz, justifiquem a recusa da exibição; VI - houver disposição legal que justifique a recusa da exibição. Parágrafo único. Se os motivos de que tratam os incisos I a VI do caput disserem respeito a apenas uma parcela do documento, a parte ou o terceiro exibirá a outra em cartório, para dela ser extraída cópia reprográfica, de tudo sendo lavrado auto circunstanciado.

${ }^{49}$ Art. 379, CPC/15: Preservado o direito de não produzir prova contra si própria, incumbe à parte: I comparecer em juízo, respondendo ao que lhe for interrogado; II - colaborar com o juízo na realização de inspeção judicial que for considerada necessária; III - praticar o ato que lhe for determinado.

${ }^{50}$ WAMBIER, Teresa Arruda Alvim (et. al.). Primeiros comentários ao novo código de processo civil: artigo por artigo. 2. Ed. São Paulo: Revista dos Tribunais, 2016. p. 733; e RAMOS, op. cit., p. 104/108.

${ }^{51}$ GAJARDONI, Fernando da Fonseca; DELLORE, Luiz; ROQUE, André Vasconcelos; OLIVEIRA JR., Zulmar Duarte de. Processo de conhecimento e cumprimento de sentença: comentários ao CPC de 2015. Rio de Janeiro: Forense, 2016. p. 297.

${ }^{52}$ Nelson Nery Jr. e Rosa Maria Andrade Nery afirmam que "O juiz não pode compelir a parte a fazer prova contra si mesma, pois tal medida seria inconstitucional”. NERY JÚNIOR, Nelson; NERY, Rosa Maria de Andrade. Código de Processo Civil Comentado. 16. Ed. São Paulo: Revista dos Tribunais, 2016. p. 1097.

${ }^{53}$ Neste sentido, Calamandrei declara que, em um interrogatório, por exemplo, "a parte adversária não tem o dever jurídico de dizer a verdade (que no processo não poderia ser afirmado sem destruir o direito de defesa), e acaso, num processo de tipo dispositivo fundado na distribuição da carga probatória, se pode até chegar a duvidar se tem o dever moral de fazê-lo" e complementa: "A parte não tem o dever jurídico de dizer em juízo a verdade no seu próprio dano.” (CALAMANDREI, op. cit, p. 243/245).

${ }^{54}$ MITIDIERO, op. cit, p. 70.
} 
Revista Eletrônica de Direito Processual - REDP.

Rio de Janeiro. Ano 11. Volume 18. Número 1. Janeiro a Abril de 2017

Periódico Quadrimestral da Pós-Graduação Stricto Sensu em Direito Processual da UERJ

Patrono: José Carlos Barbosa Moreira. ISSN 1982-7636. pp. 325-345

www.redp.uerj.br

Além disso, a Constituição Federal também limita a produção de prova, vez que veda a utilização de prova ilícita ${ }^{55}$, sendo ela aquela produzida em violação a outros direitos, ou seja, quando "o interesse no encontro da verdade cede diante de exigências superiores de proteção dos direitos materiais que podem ser violados" ${ }^{\text {. }}$. Logo, por mais que o direito a prova possa ser considerado um direito fundamental, outros direitos fundamentais podem limitar a sua produção ${ }^{57}$, restando evidente que o direito à prova não é um direito irrestrito, passível, portanto, de ponderação e razoabilidade, tendo em vista os inúmeros direitos a serem garantidos pelo nosso ordenamento jurídico.

Sendo, então, correta a assertiva de que há a inatingibilidade da verdade no processo, o órgão jurisdicional irá basear a sua decisão em uma verossimilhança ${ }^{58 / 59}$, em uma verdade factível $^{60}$, ou em uma verdade possível ${ }^{61}$ mas, não escapamos de outra afirmativa importante, qual seja, de que o processo deve se direcionar à busca da verdade ${ }^{62}$, buscando se aproximar do seu máximo possível, não podendo ser pautado por alegações e provas sabidamente falsas. Entretanto, esta não é a sua finalidade, tendo em vista que é inatingível. A finalidade do processo é a decisão justa ${ }^{63}$, firmada pelo juiz por uma verossimilhança, baseada na valoração das provas trazidas pelas partes a respeito de suas alegações.

\footnotetext{
${ }^{55}$ Art. $5^{\circ}$, LVI, CF/88. São inadmissíveis, no processo, as provas obtidas por meios ilícitos;

${ }^{56}$ MARINONI; ARENHART, op. cit, p. 302.

${ }^{57}$ À título de exemplo, o direito fundamental à integridade física e psíquica, que limita a coleta do DNA. RAMOS, op. cit, pg. 108

${ }^{58}$ Calamandrei utiliza o termo verossimilitude para tratar da veracidade de um fato: "quando se diz que um fato é verdadeiro, se quer dizer em substância que tem conseguido, na consciência de quem como tal o julga, aquele grau máximo de verossimilitude que, em relação aos limitados meios de conhecimento que o julgador dispõe, basta para lhe dar a certeza subjetiva de que aquele fato tem ocorrido" (CALAMANDREI, op. cit, p. 270).

${ }^{59}$ Termo utilizado por Zulmar Duarte de Oliveira Jr. para caracterizar o objetivo alcançável da instrução probatória; o autor afirma que escolheu este termo não em referência àquilo que normalmente acontece, mas sim "como expressivo da demonstração da verdade das proposições de fato, sendo o parâmetro de referência as provas do processo". Ainda, faz uma crítica aos conceitos que contém a expressão "verdade", tendo em vista que a verdade é apenas uma. (GAJARDONI; DELLORE; ROQUE; OLIVEIRA JR., op. cit, p. 213).

${ }^{60}$ Termo utilizado em crítica à "verossimilhança", tendo em vista que nem sempre a "verdade factível” será fundada naquilo que "regularmente acontece". (MARINONI; ARENHART, op. cit, p. 46-47).

${ }^{61}$ Expressão utilizada por Daniel Amorim Assumpção Neves, também em crítica à "verossimilhança". (NEVES, op. cit, p. 647/648).

${ }^{62}$ Calamandrei já afirmava que, por mais que a decisão seja pautada pela verossimilitude, é necessário que o procedimento busque a investigação da verdade, para que o espaço entre verdade e verossimilitude diminua o máximo. (CALAMANDREI, op. cit, p. 298).

63 TARUFFO, Michele. Verdade negociada? Revista Eletrônica de Direito Processual - REDP., ano 8, Vol. XIII, jan/jun. De 2014, p. 634/657. Trad. Pedro Gomes de Queiroz. Disponível em: [http://www.epublicacoes.uerj.br/index.php/redp/article/download/11928/9340] Acesso em 17/09/2015.
} 
Revista Eletrônica de Direito Processual - REDP.

Rio de Janeiro. Ano 11. Volume 18. Número 1. Janeiro a Abril de 2017

Periódico Quadrimestral da Pós-Graduação Stricto Sensu em Direito Processual da UERJ

Patrono: José Carlos Barbosa Moreira. ISSN 1982-7636. pp. 325-345

www.redp.uerj.br

\section{Convenções processuais sobre limitação a meios de prova}

Assimilando a verdade como uma abstração inalcançável, pode-se concluir que "a busca da verdade não é um fim em si mesmo, apenas funcionando como um dos fatores para a efetiva realização da justiça, por meio de uma prestação jurisdicional boa e de qualidade" ${ }^{64}$. Nesta senda, cumpre ressaltar que a análise dos fatos não é o único requisito para que a decisão seja considerada justa, uma vez que a correta aplicação das normas é essencial ${ }^{65}$, não se esquecendo que a correta interpretação e aplicação das normas, nesse contexto é, de igual forma, fundamental, razão pela qual se pode considerar que tanto as normas processuais, quanto as normas negociadas, devem ser obedecidas e corretamente aplicadas, “afinal, no Estado de Direito, não é só a norma legislada que deve ser aplicada pelo juiz, mas também a norma convencional definida no limite da autonomia privada"66.

Conforme já referido, a liberdade é um direito fundamental, previsto no artigo $5^{\circ}$, caput, da Constituição Federal de $1988^{67}$, sendo a autonomia privada um subprincípio aplicável ao processo civil ${ }^{68}$, principalmente neste novo modelo de processo, no qual a participação das partes é valorizada. Como afirma Fredie Didier Jr., a "autonomia privada ou autorregramento da vontade é um dos pilares da liberdade e dimensão inafastável da dignidade da pessoa humana". 69

Tendo em vista que um direito pode vir a restringir outro, a convenção processual que limita os meios de prova considerados lícitos encontra-se legitimada pelo direito fundamental à liberdade. Ainda, por se tratar de uma norma negociada, onde "as partes vinculam-se por sua autonomia e liberdade" ${ }^{70}$, esta convenção processual tem validade entre as partes, que não poderão protestar em juízo pela realização da instrução processual em relação àquele meio considerado agora ilícito ${ }^{71}$.

\footnotetext{
${ }^{64}$ NEVES, op. cit, p. 648

65 TARUFFO, op. cit.

${ }^{66}$ CABRAL, Antonio do Passo. Convenções processuais. Salvador: Juspodivm, 2016. p. 226.

${ }^{67}$ Art. 5o, CF/88: Todos são iguais perante a lei, sem distinção de qualquer natureza, garantindo-se aos brasileiros e aos estrangeiros residentes no País a inviolabilidade do direito à vida, à liberdade, à igualdade, à segurança e à propriedade, nos termos seguintes.

${ }^{68}$ DIDIER JR., Fredie. Princípio do respeito ao autorregramento da vontade no processo civil. In: CABRAL, Antonio do Passo; NOGUEIRA, Pedro Henrique (coord.). Negócios Processuais. $2^{\text {a }}$ ed., rev., atual., ampl. Salvador, Ed. Juspodivm, 2016 - pg. 32

${ }^{69}$ DIDIER JR. Curso..., op. cit, p. 133.

${ }^{70}$ CABRAL, op. cit, p. 226.

${ }^{71}$ Neste sentido, Nelson Nery Jr. e Rosa Maria Andrade Nery expõem: “em se tratando de direito a respeito do qual se permite autocomposição, é possível às partes a celebração de negócio jurídico processual que lhes
} 
Revista Eletrônica de Direito Processual - REDP.

Rio de Janeiro. Ano 11. Volume 18. Número 1. Janeiro a Abril de 2017

Periódico Quadrimestral da Pós-Graduação Stricto Sensu em Direito Processual da UERJ

Patrono: José Carlos Barbosa Moreira. ISSN 1982-7636. pp. 325-345

www.redp.uerj.br

Agora, esta convenção processual limitadora dos meios de prova vincula o juiz? Há quem diga, baseado em uma concepção publicística do processo civil, que as convenções processuais não podem limitar os poderes instrutórios do juiz, uma vez que as partes não podem dispor de ônus, poderes, faculdades ou deveres alheios; ademais, não se pode limitar a busca da verdade, sob pena de gerar decisões injustas ${ }^{72}$. Ainda, é sustentada a tese de que a limitação aos meios de prova não poderia ocorrer, por ser o ato de provar considerado um dever e os deveres não poderem ser reduzidos, apenas majorados. ${ }^{73}$

Salienta-se que o ato de provar não pode ser considerado um dever, em respeito ao devido processo legal, em especial à ampla defesa, e ao modelo cooperativo de processo. Portanto, na perspectiva do artigo 190 do Código de Processo Civil de 2015, as partes podem dispor sobre tal ato.

Além disso, a busca da verdade já é limitada pelo próprio sistema jurídico e, portanto, a verdade é inalcançável no processo. Assim, “o estabelecimento de limitações consensuais é apenas mais uma possibilidade autorizada pelo ordenamento". ${ }^{74}$ Deste modo, "o rechaço aos acordos probatórios enseja, na realidade, uma recusa a admitir o autorregramento da vontade no processo e revela a exacerbação do protagonismo judicial". ${ }^{75}$ Sendo, portanto, a instrução probatória limitada pelo próprio ordenamento, não há qualquer justificativa para que esta não possa ser limitada pela vontade das partes, com base no autorregramento da vontade e no direito à liberdade, em razão de estas serem as maiores interessadas na decisão do caso concreto. Portanto, pode-se considerar injusta uma decisão que não respeite a vontade das partes.

É claro que as limitações de meios de prova serão usualmente pactuadas em uma fase pré-processual $^{76}$, na qual ambas as partes buscam a solução adequada e efetiva para um

aprouver, respeitados os limites da constitucionalidade, e ordem pública da disposição de vontade.[...] São admissíveis, entre outros, negócios processuais que: [...] d) dispensem determinada prova (e.g. pericial);" (NERY JÚNIOR; NERY, op. cit, p. 762).

${ }^{72}$ Neste sentido: Neste sentido: WAMBIER, op. cit, p. 715/716; RAMOS, op. cit, p. 73; MARINONI, Luiz Guilherme; ARENHART, Sergio Cruz; MITIDIERO, Daniel. Novo Código de Processo Civil Comentado. $2^{a}$ ed. rev., atual, ampl. São Paulo: Ed. Revista dos Tribunais, 2016 - pg. 309; NEVES, op. cit, p. $322 / 323$.

${ }^{73}$ WAMBIER, op. cit, p. 402.

${ }^{74}$ GODINHO, A possibilidade..., In: CABRAL; NOGUEIRA, op. cit, p. 551.

${ }^{75}$ Ibid., loc. cit.

${ }^{76}$ CADIET afirma que os acordos processuais que versem sobre cláusulas relativas a um litígio são mais propícios de serem firmados em um momento pré-processual, tendo em vista que "En ese momento, evidentemente, existe un acuerdo entre las partes y este les permite considerar, fría y serenamente, la possibilidad de incumplimiento de sus obligaciones y uma solución para ese hipotético desacuerdo. Sin ninguna duda, es más fácil ponerse de acuerdo em la manera de resolver um litigio que no há comenzado que 
Revista Eletrônica de Direito Processual - REDP.

Rio de Janeiro. Ano 11. Volume 18. Número 1. Janeiro a Abril de 2017

Periódico Quadrimestral da Pós-Graduação Stricto Sensu em Direito Processual da UERJ

Patrono: José Carlos Barbosa Moreira. ISSN 1982-7636. pp. 325-345

www.redp.uerj.br

eventual litígio que possa vir a surgir. Sendo assim, caso seja instaurando um processo judicial, nenhuma das partes poderá se valer da produção de provas para postergar o proferimento da decisão, ou até mesmo para induzir o proferimento decisão injusta. Ora, se a prova pericial se mostra suficiente para comprovar o fato alegado, por que protestar por prova testemunhal? Ou, se a prova documental é satisfatória, por que solicitar prova pericial?

Um exemplo de possibilidade de limitação do meio de prova em um contrato préprocessual pode ser verificado em um Contrato Social que, em caso de liquidação judicial ou apuração de haveres, obriga as partes a produzirem prova pericial contábil em processo futuro, vinculada, inclusive, à utilização de uma determinada metodologia, como balanço determinado ou fluxo de caixa descontado, proibindo, ainda, a prova testemunhal.

A limitação ao juízo de cognição, ainda, não impede a formação de precedentes. Tais precedentes podem dizer respeito à própria negociação, como, por exemplo, a admissibilidade e validade de uma convenção processual em um caso concreto, bem como à razão de decidir sobre a situação fática daquele caso concreto em que a convenção foi firmada ${ }^{77}$. Portanto, não há justificativa para restrição das convenções processuais no âmbito dos meios de prova em prol do interesse público, tendo em vista que incidirá a segurança jurídica, de modo que os casos semelhantes serão tratados de forma semelhante e as decisões continuarão servindo para induzir o comportamento social. Ainda, qualquer negócio processual irá atingir a esfera do juiz, não sendo uma exclusividade daqueles que versem sobre o direito probatório ${ }^{78}$.

Ademais, tem-se que analisar que este "poder" instrutório ${ }^{79}$ é subsidiário ao poder das partes, tendo em vista que só será exercido quando houver lacunas probatórias. Isto é,

solucionar um litigio ya existente." (CADIET, Loïc. Los acuerdos procesales em derecho francés: situación actual de la contractualizacion de processo y de la justicia em Francia. Civil Procedure Review, v. 3, n. 3, p. 3-35, ago./dez. 2012. $\quad$ Disponível em: $<$ http://www.civilprocedurereview.com/index.php?option=com_content \& view=article \&id=280\%3A-losacuerdos-procesales-en-derecho-frances-situacion-actual-de-la-contractualizacion-del-proceso-y-de-lajusticia-en-francia\&catid=68\%3Apdf-revista-n3-2012\&Itemid=100\&lang=pt>). Acesso em: 01/10/2016.

${ }^{77}$ ABREU, Rafael Sirangelo de. A igualdade e os negócios processuais. In: CABRAL, Antonio do Passo; in NOGUEIRA, Pedro Henrique (coord.). Negócios Processuais. 2. Ed. Salvador: Juspodivm, 2016. p. 301.

${ }^{78}$ GODINHO, A possibilidade..., In: CABRAL; NOGUEIRA, op. cit, p. 550.

${ }^{79}$ A visão de Daniel Amorim Assumpção Neves, da qual somos simpatizantes, não considera a instrução de ofício como um poder do juiz, mas sim uma faculdade, tendo em vista que quando o juiz não exerce este "poder" e julga com base na regra do ônus da prova, a decisão não é considerada nula (NEVES, op. cit, p. 665). Neste sentido, Zulmar Duarte Jr. expõe que "a colocação desse dever-poder de instrução dentro do capítulo das provas, não estando mais inserido dentro dos típicos poderes do juiz [...] diminui a sua feição enquanto poder" (GAJARDONI; DELLORE; ROQUE; OLIVEIRA JR., op. cit, p. 237). 
Revista Eletrônica de Direito Processual - REDP.

Rio de Janeiro. Ano 11. Volume 18. Número 1. Janeiro a Abril de 2017

Periódico Quadrimestral da Pós-Graduação Stricto Sensu em Direito Processual da UERJ

Patrono: José Carlos Barbosa Moreira. ISSN 1982-7636. pp. 325-345

www.redp.uerj.br

será utilizando quando as partes forem inertes no que tange a produção de provas, ou seja, quando se olvidarem de pugnar pela produção de uma determinada prova, ou considerarem que tal produção seria impertinente. Contudo, na hipótese de as partes se manifestarem expressamente contra a produção de uma determinada prova por um determinado meio, o juiz não pode determinar a sua produção de ofício, tendo em vista o seu poder subsidiário e a norma negocial aplicada ao caso concreto. Deste modo, "se os poderes do juiz forem subordinados pelo agir das partes, é possível que o exercício da autonomia, por meio dos acordos, reduza ou impeça a atuação judicial" ${ }^{\prime \prime 0}$.

A contratualização sobre a ilicitude de um determinado meio de prova não torna a "verdade negociada" 81 , tendo em vista que a prova poderá ser produzida por outro(s) meio(s $)^{82}$. Neste sentido, "não é um negócio que fixa a verdade, mas um negócio que estabelece como o fato poderá ser provado". ${ }^{83}$

Além disso, a prova não se destina apenas ao juiz, mas também às partes e demais interessados ${ }^{84}$. Ora, se as partes do processo são aquelas diretamente afetadas pela decisão, uma decisão injusta não seria aquela que limita a sua autonomia quando preenchidos os requisitos legais para o seu exercício?

As partes é que melhor podem falar em nome de seus interesses, que têm maior conhecimento dos fatos alegados e que têm maior interesse na demanda processual. Assim, no momento em que, em grau de paridade, obedecido o critério isonômico e o contraditório, elas formam um negócio jurídico processual limitando os meios de prova passíveis de serem utilizados no processo, tal negócio merece ser respeitado, em observância à liberdade ${ }^{85}$, ao princípio do autorregramento da vontade e do devido processo legal.

\footnotetext{
${ }^{80}$ CABRAL, op. cit, p. 226.

${ }^{81}$ Expressão utilizada por Michele Taruffo em artigo que versa sobre a impossibilidade de se negociar acerca do direito probatório. Afirma o autor que: "O processo justo se é sistematicamente orientado a fazer com que se averigúe a veracidade dos fatos relevantes para a decisão, e é injusto na medida em que obstaculiza ou limita esta averiguação." (TARUFFO, 2014, op. cit.).

${ }^{82}$ Neste mesmo sentido, Beclaute Oliveira Silva: "Não será a verdade que está a ser negociada, mas os meios para descobri-la ou construí-la, a depender da perspectiva adotada". SILVA, Verdade como objeto..., In: CABRAL; NOGUEIRA, 2016, p. 521.

${ }^{83}$ Ibid., p. 539.

${ }^{84}$ FPPC, enunciado n. 50: Os destinatários da prova são aqueles que dela poderão fazer uso, sejam juízes, partes ou demais interessados, não sendo a únicafuncão influir eficazmente na conviccão do juiz. (Grupo: Direito Probatório)

85 "No estado democrático de direito não se pode defender a ideologia in dubio pro autoritate. Havendo duvida, deve ser homologado o negócio jurídico processual porque in dubio prolibertate" (NERY JÚNIOR; NERY, op. cit, p. 761).
} 
Revista Eletrônica de Direito Processual - REDP.

Rio de Janeiro. Ano 11. Volume 18. Número 1. Janeiro a Abril de 2017

Periódico Quadrimestral da Pós-Graduação Stricto Sensu em Direito Processual da UERJ

Patrono: José Carlos Barbosa Moreira. ISSN 1982-7636. pp. 325-345

www.redp.uerj.br

Contudo, é preciso analisar se no acordo incidem as restrições previstas no parágrafo único do artigo 190, quais sejam: situações de nulidade, inserção abusiva em contrato de adesão ou de manifesta vulnerabilidade. Deste modo, se a cláusula não é nula, se não prejudica aderente no contrato de adesão ou se os contratantes se encontrarem em situação isonômica, não há porque proibir a convenção sobre a ilicitude da prova, com fulcro no autorregramento da vontade.

Cumpre ressaltar que a vulnerabilidade deve ser manifesta, ou seja, não será qualquer vulnerabilidade que invalidará o negócio jurídico, posto que os sujeitos contratantes, de modo algum, terão condições idênticas em uma relação jurídica. Nesta senda, a isonomia entre as partes deve ser analisada no momento da formação da convenção, isto é, no momento da manifestação da vontade, e não no momento do resultado daquelas normas convencionais $^{86}$, uma vez que a autonomia da vontade não será dirimida frente "uma má escolha consciente acerca de uma estratégia processual". ${ }^{87}$

É importante salientar que, no que tange à limitação do juízo de cognição, o ônus da prova $^{88}$ irá atuar através de suas duas funções: subjetiva e objetiva. Enquanto a sua função subjetiva determina a regra de organização da atividade probatória das partes, a regra objetiva determina a regra de julgamento a ser utilizada pelo juiz em caso de insuficiência probatória para formar a convicção judicial ${ }^{89}$. Assim, no momento da manifestação de vontade ao convencionar sobre a limitação dos meios de prova, as partes devem estar cientes da função subjetiva do ônus probatório, ou seja, devem ter o conhecimento que tal convenção irá afetar o seu encargo probatório no processo, podendo gerar uma insuficiência probatória. Nesta senda, quando tal situação ocorrer, o juiz não se eximirá de prestar a atividade jurisdicional, tendo em vista que poderá basear a sua decisão na regra de julgamento do ônus da prova, julgando em desfavor daquele que não se desincumbiu do seu ônus. ${ }^{90}$

\footnotetext{
${ }^{86}$ ABREU, A igualdade..., In: CABRAL; NOGUEIRA, 2016, p. 298.

${ }^{87}$ Ibid., p. 298.

${ }^{88}$ Art. 373, CPC/15. O ônus da prova incumbe: I - ao autor, quanto ao fato constitutivo de seu direito; II - ao réu, quanto à existência de fato impeditivo, modificativo ou extintivo do direito do autor.

${ }^{89}$ CARPES, Artur. Ônus dinâmico da prova. Porto Alegre: Livraria do Advogado, 2010. p. 52.

${ }^{90}$ Alexandre Freitas Câmara compartilha deste mesmo entendimento e afirma, ainda, que é válida a convenção processual que limita determinado meio de prova, tendo em vista que as partes são titulares do ônus de provar e podem acordar sobre o não pagamento dos honorários periciais ou não indicação de testemunhas, por exemplo. CÂMARA, Alexandre Freitas. O novo processo civil brasileiro. 2. Ed. São Paulo: Atlas, 2016. p. 125.
} 
Revista Eletrônica de Direito Processual - REDP.

Rio de Janeiro. Ano 11. Volume 18. Número 1. Janeiro a Abril de 2017

Periódico Quadrimestral da Pós-Graduação Stricto Sensu em Direito Processual da UERJ

Patrono: José Carlos Barbosa Moreira. ISSN 1982-7636. pp. 325-345

www.redp.uerj.br

Cumpre referir que o ônus da prova é dinâmico, podendo ser invertido por lei ou decisão judicial (art. 373, $\S 1^{\circ}, \mathrm{CPC} / 15^{91}$ ) e, assim como a limitação dos meios probatórios, o ônus da prova também pode ser convencionado ${ }^{92}$.

Diante do exposto, pode-se concluir que o direito fundamental à liberdade, assim como os princípios do autorregramento da vontade no processo civil, da ampla defesa do contraditório e do devido processo legal, servem como ponderação à busca autoritária da verdade, em prol de uma decisão justa. Sendo assim, a válida convenção das partes sobre a limitação dos meios de prova admissíveis no processo, além de vincular automaticamente as próprias partes, vincula também o juiz, limitando o seu juízo de cognição.

\section{Considerações finais.}

O objetivo do presente estudo foi demonstrar a possibilidade de vincular as partes e o juiz a uma convenção processual limitadora dos meios de prova. A legitimação desta convenção processual encontra-se, no ordenamento jurídico brasileiro, no artigo 190 do Código de Processo Civil, pelos princípios do autorregramento da vontade, do contraditório, do devido processo legal e da ampla defesa, bem como norteado pela nova roupagem da matéria processual: o modelo cooperativo. O Novo Código de Processo Civil, totalmente elaborado em um Estado Democrático de Direito, busca uma divisão de trabalho equilibrada entre partes e juiz a fim de se alcançar uma decisão de mérito justa, efetiva e em tempo razoável (art. $\left.6^{\circ}, \mathrm{CPC} / 15\right)$. Não à toa, concedeu maior espaço à atuação das partes na condução do processo e maior valorização ao autorregramento da vontade.

Sendo uma das finalidades do Estado Constitucional a liberdade, o Novo Código implementou uma cláusula geral que permite a conformação do procedimento e posições processuais das partes por meio da autonomia da vontade (art. 190, CPC/15), que acabou por concretizar a possibilidade de maior atuação das partes na condução do processo,

\footnotetext{
${ }^{91}$ Art. 373, $\$ 1^{o}, C P C / 15$ Nos casos previstos em lei ou diante de peculiaridades da causa relacionadas à impossibilidade ou à excessiva dificuldade de cumprir o encargo nos termos do caput ou à maior facilidade de obtenção da prova do fato contrário, poderá o juiz atribuir o ônus da prova de modo diverso, desde que o faça por decisão fundamentada, caso em que deverá dar à parte a oportunidade de se desincumbir do ônus que lhe foi atribuido.

${ }^{92}$ Art. 373, $\$ 3^{\circ}, C P C / 15$. A distribuição diversa do ônus da prova também pode ocorrer por convenção das partes, salvo quando: I - recair sobre direito indisponível da parte; II - tornar excessivamente difícil a uma parte o exercício do direito.
} 
Revista Eletrônica de Direito Processual - REDP.

Rio de Janeiro. Ano 11. Volume 18. Número 1. Janeiro a Abril de 2017

Periódico Quadrimestral da Pós-Graduação Stricto Sensu em Direito Processual da UERJ

Patrono: José Carlos Barbosa Moreira. ISSN 1982-7636. pp. 325-345

www.redp.uerj.br

prevista pelo modelo cooperativo. Apesar de se tratar de uma cláusula aberta, esta norma deve ser interpretada de acordo com o ordenamento jurídico, sendo passível de sofrer limitações, como, por exemplo, aquela imposta pelo seu parágrafo único ${ }^{93}$.

Assim sendo, tendo em vista que a verdade é apenas uma e inalcançável no processo, a prova se destina ao convencimento do juiz sobre aquilo alegado pelas partes durante o processo ${ }^{94}$, onde o magistrado proferirá uma decisão baseado em uma verossimilhança ${ }^{95}$. Isto, pois, não bastasse a subjetividade da percepção do fato, há uma limitação à produção de provas imposta pelo próprio Código de Processo Civil (art. 370, parágrafo único; art. 374; art. 388; art. 379; e art. 404) e pela Constituição Federal (art. 5º, LVI), frente os inúmeros direitos a serem garantidos pelo nosso ordenamento jurídico.

Assim, frente a tantas limitações, a finalidade do processo não pode ser considerada a busca da verdade, mas sim a decisão justa, baseada em um juízo de verossimilhança. Para que a decisão seja considerada justa, deve haver a correta aplicação das normas ${ }^{96}$, aqui incluídas as normas negociadas, com fulcro na liberdade e no autorregramento da vontade, razão pela qual a convenção processual que limita os meios de prova admissíveis tem validade entre as partes e as vincula de forma automática.

Há, entretanto, certa resistência da doutrina ${ }^{97}$ em aceitar essa vinculação também ao juiz, tendo em vista o caráter publicístico do processo, o poder instrutório do magistrado e a perquirição pela verdade em prol de uma decisão justa. Num primeiro momento, a leitura permite compreender que o ato de provar não pode ser considerado um dever, sendo visto apenas como uma faculdade e um ônus, em respeito ao devido processo legal, em especial à ampla defesa, e ao modelo cooperativo de processo. Portanto, na perspectiva do artigo 190 do Código de Processo Civil, a prova pode ser objeto da convenção processual. Além disso, como a busca da verdade já é limitada pelo próprio ordenamento, não há óbice de mais um tipo de limitação: a limitação consensual. Ademais, a limitação ao juízo de cognição não se

\footnotetext{
${ }^{93}$ Art. 190, CPC/15. Versando o processo sobre direitos que admitam autocomposição, é lícito às partes plenamente capazes estipular mudanças no procedimento para ajustá-lo às especificidades da causa e convencionar sobre os seus ônus, poderes, faculdades e deveres processuais, antes ou durante o processo. Parágrafo único. De ofício ou a requerimento, o juiz controlará a validade das convenções previstas neste artigo, recusando-lhes aplicação somente nos casos de nulidade ou de inserção abusiva em contrato de adesão ou em que alguma parte se encontre em manifesta situação de vulnerabilidade.

${ }^{94}$ MARINONI; ARENHART, op. cit, p. 63.

95. GAJARDONI; DELLORE; ROQUE; OLIVEIRA JR., op. cit, p. 213.

96 TARUFFO, 2014, op. cit.

${ }^{97}$ Ver notas de rodapé n. 69 e 70
} 
Revista Eletrônica de Direito Processual - REDP.

Rio de Janeiro. Ano 11. Volume 18. Número 1. Janeiro a Abril de 2017

Periódico Quadrimestral da Pós-Graduação Stricto Sensu em Direito Processual da UERJ

Patrono: José Carlos Barbosa Moreira. ISSN 1982-7636. pp. 325-345

www.redp.uerj.br

justifica em nome do interesse público, posto que este permanecerá preservado, tendo em vista a possibilidade de formação de precedentes e de modelo para balizamento do comportamento social.

Outrossim, como qualquer convenção processual acaba por atingir a esfera de atuação do juiz em um determinado grau, foi necessária a análise sobre a natureza do poder instrutório do juiz, se autônomo ou subsidiário ao poder das partes, tendo em vista que a prova é destinada a todos os sujeitos do processo. Sustentamos que tal poder do magistrado seria subsidiário ao das partes, utilizado quando estas forem inertes no que diz respeito à instrução probatória. Diante disso, o juiz estaria, portanto, vinculado à convenção processual limitadora dos meios de prova, não podendo exercer seu poder instrutório de ofício para determinar a produção da prova por aquele meio agora inadmissível. Ressalta-se que a convenção em questão limita apenas os meios a se provar um fato e não convenciona sobre a própria verdade em si.

Logo, sendo a finalidade do processo a busca de uma decisão justa, uma decisão injusta pode ser considerada aquela proferida em oposição à vontade manifestada das partes, com fulcro no princípio do autorregramento da vontade, quando exercida em conformidade com os requisitos legais (previstos no parágrafo único do art. 190, CPC/15). Diante de uma convenção processual limitadora dos meios de prova admissíveis no processo civil, pode ocorrer - mas, não necessariamente - a insuficiência probatória para formar a convicção judicial. Mas, mesmo assim, o juiz não se eximirá de prestar a atividade jurisdicional, tendo em vista que poderá basear a sua decisão na regra de julgamento do ônus da prova, julgando em desfavor daquele que não se desincumbiu do ônus que lhe cabia. ${ }^{98}$

Conclui-se, portanto, que tanto as partes, quanto o próprio magistrado se vinculam à convenção processual limitadora dos meios de prova, quando válidas, em atenção a princípios constitucionais e normas fundamentais processuais, é seguramente cabível. Espera-se que o Poder Judiciário aplique o Novo Código de Processo Civil com um novo olhar, sob uma nova perspectiva, com atenção especial à liberdade e, consequentemente, ao autorregramento da vontade, sem deixar de se preocupar, entretanto, com a necessidade de haver isonomia entre as partes. Diante de inúmeros princípios e cláusulas abertas no nosso

${ }^{98}$ CARPES, op. cit, p. 52 
Revista Eletrônica de Direito Processual - REDP.

Rio de Janeiro. Ano 11. Volume 18. Número 1. Janeiro a Abril de 2017

Periódico Quadrimestral da Pós-Graduação Stricto Sensu em Direito Processual da UERJ

Patrono: José Carlos Barbosa Moreira. ISSN 1982-7636. pp. 325-345

www.redp.uerj.br

ordenamento, será papel do Judiciário analisar as limitações às convenções processuais nos casos concretos.

\section{REFERÊNCIAS BIBLIOGRÁFICAS.}

ABREU, Rafael Sirangelo de. “Customização processual compartilhada": o sistema de adaptabilidade do novo CPC. Revista de Processo, vol. 257, jul/2016.

ABREU, Rafael Sirangelo de. A igualdade e os negócios processuais. In: CABRAL, Antonio do Passo; NOGUEIRA, Pedro Henrique (coord.). Negócios Processuais. 2. Ed. Salvador: Juspodivm, 2016.

AMARAL, Paulo Osternack. Provas: atipicidade, liberdade e instrumentalidade. São Paulo: Revista dos Tribunais, 2015.

BEDAQUE, José Roberto dos Santos. Direito e processo: influência do direito material sobre o processo. 5. ed. São Paulo: Malheiros, 2009.

BRASIL. Constituição (1998). Constituição da República Federativa do Brasil de 1988.

Disponível em:

<http://www.planalto.gov.br/ccivil_03/constituicao/constituicao.htm>. Acesso em 27/09/2016

BRASIL. Lei $\mathbf{n}^{\mathbf{0}}$ 13.105, de 16 de março de 2015. Institui o Código de Processo Civil. Disponível em <http://www.planalto.gov.br/ccivil_03/_ato20152018/2015/lei/113105.htm>. Acesso em 27/09/2016

BRASIL. Lei n. 5.869, de 11 de janeiro de 1973. Institmi a Código de Processo Civil. Disponível em <http://www.planalto.gov.br/ccivil_03/leis/L5869.htm> Acesso em 27/09/2016

CABRAL, Antonio do Passo. Convenções processuais. Salvador: Juspodivm, 2016.

CADIET, Loïc. Los acuerdos procesales em derecho francés: situación actual de la contractualizacion de processo y de la justicia em Francia. Civil Procedure Review, v. 3, n. 3, p. 3-35, ago./dez. 2012. Disponível em: $<$ http://www.civilprocedurereview.com/index.php?option=com_content\&view=articl e\&id=280\%3A-los-acuerdos-procesales-en-derecho-frances-situacion-actual-de-lacontractualizacion-del-proceso-y-de-la-justicia-en-francia\&catid=68\%3Apdf-revistan3-2012\&Itemid=100\&lang=pt>. Acesso em: 01/10/2016. 
Revista Eletrônica de Direito Processual - REDP.

Rio de Janeiro. Ano 11. Volume 18. Número 1. Janeiro a Abril de 2017

Periódico Quadrimestral da Pós-Graduação Stricto Sensu em Direito Processual da UERJ

Patrono: José Carlos Barbosa Moreira. ISSN 1982-7636. pp. 325-345

www.redp.uerj.br

CALAMANDREI, Piero. Direito processual civil. V. 3. Trad. Luiz Abezia e Sandra Drina Fernandez Barbiery. Campinas: Bookseller, 1999.

CÂMARA, Alexandre Freitas. O novo processo civil brasileiro. 2. Ed. São Paulo: Atlas, 2016.

CARNELUTTI, Francesco. A prova civil. Trad. Amilcare Carletti. São Paulo: Livraria e Editora Universitária de Direito, 2002.

CARPES, Artur. Ônus dinâmico da prova. Porto Alegre: Livraria do Advogado, 2010.

CUNHA, Leonardo Carneiro da. Negócios Jurídicos Processuais no Processo Civil Brasileiro. In: CABRAL, Antonio do Passo; NOGUEIRA, Pedro Henrique (coord.). Negócios Processuais. 2. Ed. Salvador: Juspodivm, 2016.

DIDIER JR., Fredie. Curso de Direito Processual Civil, V. I. 18. Ed. Salvador: Juspodivm, 2016.

DIDIER JR., Fredie. Princípio do respeito ao autorregramento da vontade no processo civil. In: CABRAL, Antonio do Passo; NOGUEIRA, Pedro Henrique (coord.). Negócios Processuais. 2. Ed. Salvador: Juspodivm, 2016.

FPPC, Enunciado n. 50 - Disponível em <http://portalprocessual.com/wpcontent/uploads/2015/06/Carta-de-Vit\%C3\%B3ria.pdf> Acesso em 21/09/2016

GAJARDONI, Fernando da Fonseca; DELlORE, Luiz; ROQUE, André Vasconcelos; OLIVEIRA JR., Zulmar Duarte de. Processo de conhecimento e cumprimento de sentença: comentários ao CPC de 2015. Rio de Janeiro: Forense, 2016.

GODINHO, Robson. A possibilidade de negócios jurídicos processuais atípicos em matéria probatória. In: CABRAL, Antonio do Passo; NOGUEIRA, Pedro Henrique (coord.). Negócios Processuais. 2. Ed. Salvador: Juspodivm, 2016.

JOBIM, Marco Felix. Cultura, escolas e fases metodológicas do processo. 3. Ed. Porto Alegre: Livraria do Advogado, 2016.

LIPIANI, Júlia; SIQUEIRA, Marília. Negócios jurídicos processuais sobre mediação e conciliação. ZANETI JR., Hermes; CABRAL, Trícia Navarro Xavier (coordenadores); DIDIER JR., Fredie (coordenador geral). Justiça multiportas: mediação, conciliação, arbitragem e outros meios de solução adequada de conflitos. Salvador: Juspodivm, 2017. p. 141-167.

MARINONI, Luiz Guilherme; ARENHART, Sergio Cruz. Prova e convicção: de acordo com o CPC de 2015. São Paulo: Revista dos Tribunais, 2015. 
Revista Eletrônica de Direito Processual - REDP.

Rio de Janeiro. Ano 11. Volume 18. Número 1. Janeiro a Abril de 2017

Periódico Quadrimestral da Pós-Graduação Stricto Sensu em Direito Processual da UERJ

Patrono: José Carlos Barbosa Moreira. ISSN 1982-7636. pp. 325-345

www.redp.uerj.br

MARINONI, Luiz Guilherme; ARENHART, Sergio Cruz; MITIDIERO, Daniel. Novo

curso de processo civil: teoria do processo civil. 2. Ed. São Paulo: Revista dos Tribunais, 2016.

MARINONI, Luiz Guilherme; ARENHART, Sergio Cruz; MITIDIERO, Daniel. Novo Código de Processo Civil Comentado. $2^{\mathrm{a}}$ ed. rev., atual, ampl. São Paulo: Ed. Revista dos Tribunais, 2016

MITIDIERO, Daniel. Colaboração no Processo Civil: pressupostos sociais, lógicos e éticos. 3. Ed. São Paulo: Revista dos Tribunais, 2015.

NERY JÚNIOR, Nelson; NERY, Rosa Maria de Andrade. Código de Processo Civil Comentado. 16. Ed. São Paulo: Revista dos Tribunais, 2016.

NEVES, Daniel Amorim Assumpção. Manual de Direito Processual Civil. Volume único.

8. Ed. Salvador: Juspodivm, 2016.

RAMOS, Vitor de Paula. Ônus da prova no processo civil: do ônus ao dever de provar. São Paulo: Revista dos Tribunais, 2015.

SILVA, Beclaute de Oliveira da Silva. Verdade como objeto do negócio jurídico processual. In: CABRAL, Antonio do Passo; NOGUEIRA, Pedro Henrique (coord.). Negócios Processuais. 2. Ed. Salvador: Juspodivm, 2016.

TARUFFO, Michele. Verdade negociada? In: Revista Eletrônica de Direito Processual (REDP). Trad. Pedro Gomes de Queiroz. Ano 8, Vol. XIII, jan/jun-2014. p. 634-657. Disponível em: [http://www.epublicacoes.uerj.br/index.php/redp/article/download/11928/9340]. Acesso em: $17 / 09 / 2015$.

WAMBIER, Teresa Arruda Alvim (et. al.). Primeiros comentários ao novo código de processo civil: artigo por artigo. 2. Ed. São Paulo: Revista dos Tribunais, 2016. 